\title{
Infrared Radiation Applied as a Heating Source in Milk Sample Preparation for the Determination of Trace Elements by Inductively Coupled Plasma-Optical Emission Spectroscopy
}

\author{
Sousa, W. V.; Silva, F. L. F.; Gouveia, S. T.; Matos, W. O.; Ribeiro, L. P. D.; \\ Lopes, G. S.*
}

Rev. Virtual Quim., 2017, 9 (6), 2226-2236. Data de publicação na Web: 21 de novembro de 2017

http://rvq.sbq.org.br

Emprego da Radiação Infravermelha como Fonte de Aquecimento para o Preparo de Amostras de Leite e Determinação de Elementos Traços por Espectrometria de Emissão Óptica com Plasma Acoplado Indutivamente

\begin{abstract}
Resumo: O uso da radiação infravermelha (IR) como fonte de aquecimento no preparo de amostra de leite e análise de elementos traços por espectrometria de emissão óptica com plasma acoplado indutivamente (ICP-OES) foi investigado. Três estratégias foram estudadas: 1) um sistema que combina a radiação IR e radiação micro-ondas (IR-MW); 2) a digestão parcial utilizando apenas radiação IR; e 3) a digestão parcial utilizando a radiação IR e o pentóxido de vanádio $\left(\mathrm{V}_{2} \mathrm{O}_{5}\right)$ como catalisador $\left(I R-\mathrm{V}_{2} \mathrm{O}_{5}\right)$. Precisão e exatidão variaram de acordo com o elemento determinado. O procedimento utilizando somente radiação IR apresentou $15,1 \pm 0,3 \mathrm{mg} \mathrm{g}^{-1}$ para $\mathrm{Ca}, 0,76 \pm 0,03 \mathrm{gg} \mathrm{g}^{-1}$ para $\mathrm{Cu}, 217 \pm 2 \mu \mathrm{g} \mathrm{g}^{-1}$ para $\mathrm{Fe}, 14,8 \pm 0,7 \mathrm{mg} \mathrm{g}^{-1}$ para $\mathrm{K}, 1,17 \pm 0,03 \mathrm{mg} \mathrm{g}^{-1}$ para $\mathrm{Mg}, 4,41 \pm 0,08 \mathrm{mg} \mathrm{g}^{-1}$ para $\mathrm{Na}, 16,2 \pm 0,1 \mathrm{mg} \mathrm{g}^{-1}$ para $\mathrm{P}$ e $30,5 \pm 0,6 \mu \mathrm{g} \mathrm{g}^{-1}$ para $\mathrm{Zn}$ em amostras de leite desnatado. O uso da radiação IR para o preparo de amostras em análise de elementos traços é uma alternativa fácil de ser implementada e de baixo custo para laboratórios de análise de alimentos que não possuam forno de micro-ondas disponível.
\end{abstract}

Palavras-chave: Radiação infravermelha; leite; pentóxido de vanádio; elementos traços; ICP-OES.

\begin{abstract}
The use of infrared (IR) radiation as a heating source for milk sample preparation in trace element analysis by inductively coupled plasma optical emission spectroscopy (ICP-OES) was investigated. Three strategies were studied: 1 ) a system that combined IR and microwave radiation (IR-MW); 2) partial digestion using only IR radiation (IR); and 3) partial digestion using IR radiation and vanadium pentoxide as a catalyst $\left(\mathrm{IR}-\mathrm{V}_{2} \mathrm{O}_{5}\right)$. Accuracy varied according to the element determined. The procedure using only IR radiation presented $15.1 \pm 0.3 \mathrm{mg} \mathrm{g}^{-1}$ for $\mathrm{Ca}, 0.76 \pm 0.03 \mu \mathrm{g} \mathrm{g}^{-1}$ for $\mathrm{Cu}, 217 \pm 2 \mu \mathrm{g} \mathrm{g}^{-1}$ for Fe, $14.8 \pm 0.7$ $\mathrm{mg} \mathrm{g}^{-1}$ for $\mathrm{K}, 1.17 \pm 0.03 \mathrm{mg} \mathrm{g}^{-1}$ for $\mathrm{Mg}, 4.41 \pm 0.08 \mathrm{mg} \mathrm{g}^{-1}$ for $\mathrm{Na}, 16.2 \pm 0.1 \mathrm{mg} \mathrm{g}^{-1}$ for $\mathrm{P}$ and $30.5 \pm 0.6 \mu \mathrm{g}$ $\mathrm{g}^{-1}$ for $\mathrm{Zn}$ in non-fat milk. The use of IR radiation for sample preparation in trace element analysis is an easy to implement and a low-cost alternative for laboratories of food analysis that do not have a microwave available.
\end{abstract}

Keywords: Infrared radiation; milk; vanadium pentoxide; trace elements; ICP-OES.

* Universidade Federal do Ceará, Laboratório de Estudos em Química Aplicada (LEQA), Departamento de Química Analítica e Físico-Química, Campus do Pici, Fortaleza-CE, Brazil.

Mgslopes@ufc.br

DOI: 10.21577/1984-6835.20170132

Rev. Virtual Quim. |Vol 9| |No.6| |2226-2236| 


\title{
Infrared Radiation Applied as a Heating Source in Milk Sample Preparation for the Determination of Trace Elements by Inductively Coupled Plasma-Optical Emission Spectroscopy
}

\author{
Wellington V. de Sousa, ${ }^{\text {a }}$ Francisco Luan F. da Silva, ${ }^{b}$ Sandro T. Gouveia, ${ }^{a}$ \\ Wladiana O. Matos, ${ }^{a}$ Livia Paulia D. Ribeiro, ${ }^{b}$ Gisele Simone Lopes ${ }^{\mathrm{a}, *}$ \\ a Universidade Federal do Ceará, Laboratório de Estudos em Química Aplicada (LEQA), \\ Departamento de Química Analítica e Físico-Química, Campus do Pici, Fortaleza-CE, Brazil. \\ ${ }^{b}$ Universidade Internacional da Integração Lusofonia Afro-brasileira, Unilab, Redenção-CE, \\ Brazil. \\ *gslopes@ufc.br
}

Recebido em 31 de outubro de 2016. Aceito para publicação em 14 de novembro de 2017

\section{Introduction}

2. Material and Methods

2.1. Sample, reagents and standards

2.2. Instrumentation

2.3. Sample preparation using IR radiation

2.4. Sample preparation using radiation combined with microwave-assisted digestion (IR-MW)

\section{Results and discussion}

3.1. Application of the IR-MW system to milk sample

3.2. Application of the IR extraction procedure to milk samples

\section{Conclusion}

\section{Introduction}

Milk is a complex fluid that contains all the nutrients required for the growth and development of infants. Different kinds of milk are composed of specific proteins, fats, minerals, and other components, all of which play important nutritional roles. $^{1}$ Trace elements are natural components whose concentrations in milk may vary widely depending on factors like the breed and age of the source animal of the milk. Procedures such as heat treatment of the milk may also change the levels of mineral constituents. ${ }^{2}$ Due to its complex matrix, the determination of inorganic nutrients in milk is not a trivial task. In addition, the trace elements may be present in different forms, which can affect both samples and measurements. $^{3}$

Recent studies have reported the use of alternative techniques for milk sample 
preparation and the determination of elements by spectroanalytical techniques. Luo et al. ${ }^{4}$ have worked in the determination of essential and trace elements by FAAS and ICP-OES in human milk with microwaveassisted digestion. Bizzi et al. ${ }^{5}$ have reported the use of dilute nitric acid for complete decomposition of powdered whole milk and non-fat milk in a microwave oven using oxygen-pressurized vials; low residual carbon content and good recoveries of the elements were obtained. Pereira et $a l^{6}{ }^{6}$ have used focused microwave-induced combustion (FMIC) for milk sample preparation to decompose larger masses (up to $3 \mathrm{~g}$ ) recovered in a dilute nitric acid absorbing solution. Da Silva et al. $^{7}$ have used microwave-induced combustion (MIC) for the digestion of milk whey samples for the determination of bromine and iodine by ICPMS.

Although MIC and FMIC methods can be used to decompose high sample masses (up to $0.5 \mathrm{~g}$ with MIC and up to $3.0 \mathrm{~g}$ with $\mathrm{FMIC}$ ), both require high-cost equipment and are not easy to perform, especially considering that they require the introduction of $\mathrm{O}_{2}$ to the system, which increases both risk to the analyst and operational difficulty. It should also be noted that few research groups have focused microwave equipment available in their lab. The application of infrared (IR) radiation as a heating source in sample preparation has not been widely explored. IR promotes heating by stimulating the vibrational and rotational motions of molecules.

The use of IR is widespread in the drying of solid samples and reagents, and in the distillation of inorganic liquids under boiling point temperatures. ${ }^{8}$ Gouveia et $a l .{ }^{9}$ used a set of three tungsten lamps as a source of IR radiation to promote partial decomposition of bovine liver and apple leaves certified samples. Furthermore, Magalhães et $a l^{10}$ used three IR lamps in the presence of a stream of warm air to reach temperatures of $1100{ }^{\circ} \mathrm{C}$ in a pyrolysis chamber containing a pellet of sample for direct determination of $\mathrm{Hg}$ by cold vapor atomic absorption spectrometry.

Recently, Dantas et al. ${ }^{11}$ presented a system for the digestion of organic samples combining IR and microwave (MW) radiation (termed an IR-MW system). The IR-MW system allows the digestion of larger masses of organic samples by preliminary partial digestion using IR radiation as a heating source. The digestion was then completed in a microwave oven. Trace elements ( $\mathrm{Al}, \mathrm{Ca}$, $\mathrm{Cu}, \mathrm{Fe}, \mathrm{K}, \mathrm{Mg}, \mathrm{Mn}, \mathrm{Na}, \mathrm{P}$, and $\mathrm{Zn}$ ) in humanfeed samples were determined by ICP-OES, and more accurate results were obtained than those possible with conventional digestion. A certified whole milk powder reference material (NIST 8435) was employed, and their analyses showed 85$100 \%$ agreement with the reference values.

The decomposition temperatures reached in open systems are limited, the boiling temperature of the acid mixture $\left(120^{\circ} \mathrm{C}\right.$ in the case of $\mathrm{HNO}_{3}$ ), which may not be enough for satisfactory decomposition of organic matter, particularly in the digstion of more complex matrices. Therefore, the use of a catalyst can help to increase the efficiency of the digestion process. Vanadium pentoxide $\left(\mathrm{V}_{2} \mathrm{O}_{5}\right)$ was used in the digestion of product samples such as fermented goat's milk and cow's milk for determination of $\mathrm{Ca}, \mathrm{Mg}, \mathrm{Zn}$, and Se by flame atomic-absorption spectrometry (FAAS) and hydride generationflame atomic-absorption spectrometry (HGFAAS), using $2.0 \mathrm{~g}$ samples in a block digester. ${ }^{12}$ The main disadvantage of open systems is the large amount of time needed for sample preparation, since the heating step takes place by conduction of heat from the block digester to the sample vessel.

Consequently, we have attempted to develop and evaluate new strategies for the preparation of milk samples using IR radiation as the heating source. The procedures were evaluated by performing the trace-element analysis ( $\mathrm{Ca}, \mathrm{Cu}, \mathrm{Fe}, \mathrm{K}, \mathrm{Mg}$, $\mathrm{Mn}, \mathrm{Na}, \mathrm{P}$ and $\mathrm{Zn}$ ) of large-mass ( $2.0 \mathrm{~g}$ ) milk samples by inductively coupled plasmaoptical emission spectroscopy (ICP-OES). 


\section{Material and Methods}

\subsection{Samples, reagents and standards}

Samples of whole, and non-fat bovine milk powder were purchased in a market in the city of Fortaleza, Ceará, Brazil.

A standard whole milk powder reference material (NIST 8435, National Institute of Standards and Technology, Gaithersburg, $M D, U S A)$ was used to verify the accuracy of the proposed method.

All solutions were prepared using ultrapure water (resistivity of $18.2 \mathrm{M} \Omega \mathrm{cm}$ ) obtained from a Milli-Q water purification system (Millipore, Bedford, MA, USA). All glassware and polypropylene flasks were immersed in $10 \% \mathrm{v} \mathrm{v}^{-1}$ nitric acid (Merck, Darmstadt, Germany) for $24 \mathrm{~h}$ and rinsed with ultrapure water prior to use.

Sample digestion procedures were accomplished using 65\% w w $\mathrm{wNO}_{3}^{-1}$ (Vetec, Rio de Janeiro, Brazil), 30\% w w $w^{-1} \mathrm{H}_{2} \mathrm{O}_{2}$ (Vetec), and $\mathrm{V}_{2} \mathrm{O}_{5}$ (99\% purity, Sigma-Aldrich, St Louis, Missouri, USA). Standard reference solutions for the external calibration curve were prepared by successive dilution of 1000 $\mathrm{mg} \mathrm{L}^{-1} \mathrm{Ca}, \mathrm{Cu}, \mathrm{Fe}, \mathrm{K}, \mathrm{Mg}, \mathrm{Mn}, \mathrm{Na}, \mathrm{P}$ and $\mathrm{Zn}$ stock solutions (Acros Organics, Belgium) for final concentration of $1,5,10,15 \mathrm{mg} \mathrm{L}^{-1}$ for $\mathrm{Cu}, \mathrm{Fe}, \mathrm{Mn}$ and $\mathrm{Zn} ; 5,10,15,30 \mathrm{mg} \mathrm{L}^{-1}$ for $\mathrm{Ca}$, $\mathrm{K}, \mathrm{Na}$ and $\mathrm{P}$. All the standard solutions for external calibration were prepared in $1 \% \mathrm{w}$ $\mathrm{w}^{-1} \mathrm{HNO}_{3}$.

\subsection{Instrumentation}

The IR digestion was performed using a commercially available IR lamp (250 W, diameter: $127 \mathrm{~mm}$, length: $180 \mathrm{~mm}, \mathrm{E}-27-$ 5000h, EMPALUX, Curitiba, PR, Brazil). The vessels used for heating with the IR lamp were the same quartz vessels used in the microwave oven. During the digestion the lamp was attached to a support and the quartz vial containing the sample and reagents was positioned approximately $1 \mathrm{~cm}$ above the IR lamp.

Digestion in the IR-MW system was accomplished using the same arrangement as that used in the IR digestion, with the digestion being completed in a microwave oven (Multiwave ${ }^{\circledR}$, Anton Paar, Graz, Austria) equipped with six $50 \mathrm{~mL}$ quartz vessels (maximum temperature and pressure: $280 \stackrel{\circ}{\circ}$ and 70 bar, respectively) and a temperature sensor.

A dual-view Optima 4300 DV (Perkin Elmer) ICP-OES system was used for $\mathrm{Ca}, \mathrm{Cu}$, $\mathrm{Fe}, \mathrm{K}, \mathrm{Mg}, \mathrm{Mn}, \mathrm{Na}, \mathrm{P}$, and $\mathrm{Zn}$ determinations. The operational parameters, wavelengths of the elements, and the viewing position of the torch in the ICP-OES system are shown in Table 1.

\subsection{Sample preparation using IR radiation}

Reduction of the sample mass after the IR procedure was investigated using $1.0 \mathrm{~g}$ samples with the addition of $5.0 \mathrm{~mL}$ of $65 \% \mathrm{w}$ $\mathrm{W}^{-1} \mathrm{HNO}_{3}$. The mixture was exposed to $\mathrm{IR}$ radiation for $30 \mathrm{~min}$, and the resulting mixture was filtered, washed with water, and the solid material was dried in an oven at 60 o $\mathrm{C}$ for $24 \mathrm{~h}$. The material was weighed and the mass loss was calculated. This step is relevant when working with the IR-MW system in order to assure that the residual mass of the pre-digestion (IR) is safe enough to digest into the closed vessels of microwave cavity oven. Masses lower than 250 mg were considered optimal for complete digestion step in the microwave (MW).

The proposed IR procedure was accomplished with $2.0 \mathrm{~g}$ of sample weighed into a quartz microwave oven vessel. After the addition of $8 \mathrm{~mL}$ of $65 \% \mathrm{w} \mathrm{w}^{-1} \mathrm{HNO}_{3}$, the mixture was exposed to IR radiation for 30 min. After cooling, the solution was transferred to a polypropylene tube, diluted to $30 \mathrm{~mL}$ with ultrapure water, and filtered 
prior to ICP-OES measurements.

The IR- $\mathrm{V}_{2} \mathrm{O}_{5}$ procedure was implemented following the same steps as the IR procedure but with the addition of $5.0 \mathrm{mg}$ of $\mathrm{V}_{2} \mathrm{O}_{5}$ to the quartz vessel prior to heating with the IR lamp.

Table 1. Operational parameters used in ICP-OES for the quantification of elements

\begin{tabular}{cc}
\hline Nebulization Chamber & Double-pass \\
Nebulizer & Cross-flow \\
Alumina Injector (mm I.D) & 2.4 \\
Generator Frequency (MHz) & 40 \\
Radio-frequency power (W) & 1100 \\
Argon plasma flow rate (L min ${ }^{-1}$ ) & 15 \\
Nebulization argon flow rate (L min $\left.{ }^{-1}\right)$ & 0.8 \\
Auxiliary argon flow rate (L min $\left.{ }^{-1}\right)$ & 0.5 \\
Sample flow rate (L min $\left.{ }^{-1}\right)$ & 1.4 \\
Analytical Wavelength (nm) & \\
Ca & $317.933^{*}$ \\
$\mathrm{Cu}$ & 324.752 \\
$\mathrm{~K}$ & $766.490^{*}$ \\
$\mathrm{Fe}$ & 259.939 \\
$\mathrm{Mg}$ & $285.213^{*}$ \\
$\mathrm{Mn}$ & 257.610 \\
$\mathrm{Na}$ & $589.595^{*}$ \\
$\mathrm{P}$ & 213.617 \\
$\mathrm{Zn}$ & 213.857 \\
\hline
\end{tabular}

*This elements was quantified using a radially positioned torch, the others with an axially positioned torch

2.4. Sample preparation using infrared radiation combined with microwaveassisted digestion (IR-MW)

The IR-MW procedure was performed using $1.0 \mathrm{~g}$ samples and the addition of $5 \mathrm{~mL}$ of $65 \% \mathrm{w} \mathrm{w}^{-1} \mathrm{HNO}_{3}$. The quartz vessel was loosely covered and exposed to IR radiation for $30 \mathrm{~min}$. After the addition of $1.0 \mathrm{~mL}$ of $30 \% \mathrm{w} \mathrm{w}^{-1} \mathrm{H}_{2} \mathrm{O}_{2}$ to the mixture, it was transferred to a microwave oven and subjected to the heating program presented in Table 2. The digested solutions were then transferred and diluted to $30 \mathrm{~mL}$ with ultrapure water. 
Table 2. Heating program used for digestion in the microwave.

\begin{tabular}{ccc}
\hline Step & Power $(\mathrm{W})$ & Time $(\mathrm{min})$ \\
\hline 1 & $0-400$ & 5.0 \\
2 & 0 & 5.0 \\
3 & $0-400$ & 3.0 \\
4 & $400-800$ & 2.0 \\
5 & 800 & 3.0 \\
6 & 0 & 15.0 \\
\hline
\end{tabular}

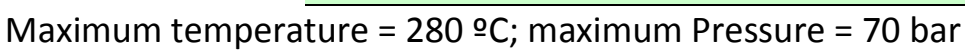

\section{Results and discussion}

The IR system was constructed according to the model proposed in a previous work in our group ${ }^{11}$. The system proposed intended to study the use of an IR lamp as a predigestion step for promoting the extraction of trace elements into solution and reduce the sample mass (and carbon content) before the microwave-assisted digestion. The IR radiation can heat samples more efficiently than traditional block heating, which makes the procedure faster, low cost, and easier to perform in a typical research laboratory, making it a promising alternative for sample preparation procedure of organic samples for trace element analysis. The IR-MW system was validated using a certified whole milk powder reference material (NIST 8435), and no statistically significant differences are observed in the obtained values at 95\% confidence (t-test). The relative standard deviations (RSDs) for the measurements were lower than $8 \%$ for all elements, except for $\mathrm{Cu}$ (33\%) and Fe (20\%). The use of larger sample mass promotes possibility of measurements of trace elements by techniques as ICP-OES with precision and accuracy. Results obtained using the IR-MW system are shown in Table 3.

Table 3. Results for the standard reference material (whole milk powder, NIST 8435), using IR-MW system (Mean \pm SD; $n=3$ )

\begin{tabular}{ccc}
\hline Elements & $\begin{array}{c}\text { Values obtained with the } \\
\text { IR-MW system }\end{array}$ & Certified Values $^{\mathrm{b}}$ \\
\hline $\mathrm{Ca}(w \mathrm{t} \%)$ & $0.90 \pm 0.03$ & $0.93 \pm 0.25$ \\
$\mathrm{Cu}\left(\mu \mathrm{g} \mathrm{g}^{-1}\right)$ & $0.53 \pm 0.18$ & $0.46 \pm 0.04$ \\
$\mathrm{Fe}\left(\mu \mathrm{g} \mathrm{g}^{-1}\right)$ & $2.04 \pm 0.41$ & $1.80 \pm 0.55$ \\
$\mathrm{~K}(w \mathrm{w} \%)$ & $1.30 \pm 0.08$ & $1.36 \pm 0.24$ \\
$\mathrm{Mg}\left(\mu \mathrm{g} \mathrm{g}^{-1}\right)$ & $819 \pm 55$ & $814 \pm 38$ \\
$\mathrm{Na}(w \mathrm{w} \%)$ & $0.33 \pm 0.02$ & $0.36 \pm 0.20$ \\
$\mathrm{P}(w t \%)$ & $0.80 \pm 0.05$ & $0.78 \pm 0.02$ \\
$\mathrm{Zn}\left(\mu \mathrm{g} \mathrm{g}^{-1}\right)$ & $27.75 \pm 0.54$ & $28.00 \pm 1.55$ \\
\hline
\end{tabular}

$\begin{array}{r}{ }^{\mathrm{a}} \text { Relative standard deviations for triplicate. }{ }^{\mathrm{b}} \text { Standard deviation for k }=2 \text { (95\% uncertainty) } \\ \hline 2231 \text { Rev. Virtual Quim. |Vol } 9 \mid \text { | No. } 6 \mid \text { |2226-2236| }\end{array}$


Sample mass reductions of $66-76 \%$ were obtained after pre-digestion of milk samples using IR radiation, representing acceptable conditions for the use of the IR-MW system in this work.

The results obtained with the IR-MW system in the present work were used for comparison and evaluation of the predigestion step in the IR lamp (IR extraction and $\mathrm{IR}+\mathrm{V}_{2} \mathrm{O}_{5}$ procedures) taking into account the determination of $\mathrm{Ca}, \mathrm{Cu}, \mathrm{Fe}, \mathrm{K}, \mathrm{Mg}, \mathrm{Mn}$, $\mathrm{Na}, \mathrm{P}$ and $\mathrm{Zn}$ by ICP-OES.

\subsection{Application of the IR-MW system to milk samples}

The IR-MW method was applied to the decomposition of non-fat and whole cow's milk powder samples. The results for trace element determinations by ICP-OES are shown in Table 4.

Table 4. Results for milk samples digested using the IR-MW system, IR and IR- $\mathrm{V}_{2} \mathrm{O}_{5}$ methods (mean $\pm S D ; n=3)$

\begin{tabular}{|c|c|c|c|c|c|c|c|c|}
\hline \multicolumn{9}{|c|}{ Milk samples } \\
\hline & & Elements & & Whole & & & Non-fat & \\
\hline \multirow{6}{*}{ 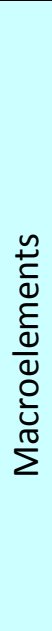 } & \multirow{6}{*}{ 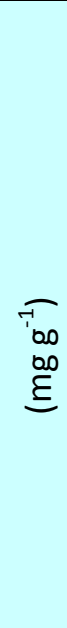 } & & IR & $\mathrm{IR}+\mathrm{V}_{2} \mathrm{O}_{5}$ & IR-MW & IR & $\mathrm{IR}+\mathrm{V}_{2} \mathrm{O}_{5}$ & IR-MW \\
\hline & & $\mathrm{Ca}$ & $\begin{array}{c}8.03 \pm \\
0.48\end{array}$ & $\begin{array}{c}9.29 \pm \\
0.14\end{array}$ & $\begin{array}{c}9.11 \pm \\
0.21\end{array}$ & $15.1 \pm 0.3$ & $15.8 \pm 2.7$ & $20.1 \pm 1.3$ \\
\hline & & $\mathrm{K}$ & $\begin{array}{c}10.1 \pm \\
0.3\end{array}$ & $\begin{array}{c}11.7 \pm \\
0.2\end{array}$ & $\begin{array}{c}11.2 \pm \\
0.2\end{array}$ & $14.8 \pm 0.7$ & $18.3 \pm 0.8$ & $20.3 \pm 1.1$ \\
\hline & & $\mathrm{Mg}$ & $\begin{array}{c}0.69 \pm \\
0.03\end{array}$ & $\begin{array}{c}0.83 \pm \\
0.02\end{array}$ & $\begin{array}{c}0.84 \pm \\
0.03\end{array}$ & $\begin{array}{c}1.17 \pm \\
0.03\end{array}$ & $1.37 \pm 0.06$ & $\begin{array}{c}1.49 \pm \\
0.08\end{array}$ \\
\hline & & $\mathrm{Na}$ & $\begin{array}{c}3.36 \pm \\
0.11\end{array}$ & $\begin{array}{c}3.79 \pm \\
0.16\end{array}$ & $\begin{array}{c}3.49 \pm \\
0.03\end{array}$ & $\begin{array}{c}4.41 \pm \\
0.08\end{array}$ & $5.30 \pm 0.22$ & $5.78 \pm 0.3$ \\
\hline & & $P$ & $\begin{array}{c}9.72 \pm \\
0.49\end{array}$ & $\begin{array}{c}11.00 \pm \\
0.2\end{array}$ & $\begin{array}{c}8.01 \pm \\
0.27\end{array}$ & $16.2 \pm 0.1$ & $17.7 \pm 1.5$ & $18.1 \pm 0.9$ \\
\hline \multirow{4}{*}{ 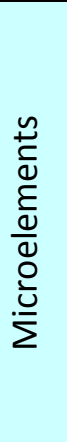 } & \multirow{4}{*}{$\begin{array}{l}\tau_{10} \\
\text { an } \\
\underline{00}\end{array}$} & $\mathrm{Fe}$ & $<0.010$ & $\begin{array}{c}0.67 \pm \\
0.22\end{array}$ & $\begin{array}{c}89.7 \pm \\
0.9\end{array}$ & $217 \pm 2$ & $252 \pm 3$ & $282 \pm 17$ \\
\hline & & $\mathrm{Cu}$ & $\begin{array}{c}0.25 \pm \\
0.02\end{array}$ & $\begin{array}{c}0.16 \pm \\
0,01\end{array}$ & $\begin{array}{c}1.16 \pm \\
0.28\end{array}$ & $\begin{array}{c}0.76 \pm \\
0.03\end{array}$ & $0.82 \pm 0.04$ & $\begin{array}{c}0.63 \pm \\
0.08\end{array}$ \\
\hline & & $\mathrm{Mn}$ & $<0.002$ & $<0.002$ & $\begin{array}{c}0.39 \pm \\
0.06\end{array}$ & $<0.002$ & $0.64 \pm 0.06$ & $<0.002$ \\
\hline & & $\mathrm{Zn}$ & $\begin{array}{c}18.6 \pm \\
0.8\end{array}$ & $\begin{array}{c}24.0 \pm \\
0.5\end{array}$ & $\begin{array}{c}32.8 \pm \\
0.8\end{array}$ & $30.5 \pm 0.6$ & $42.5 \pm 0.9$ & $38.8 \pm 1.7$ \\
\hline
\end{tabular}

The determinations of the elements using the IR-MW method show standard deviations below $10 \%$, except for $\mathrm{Cu}$ in the whole $(24 \%)$ and non-fat (13\%) milk samples, and $\mathrm{Mn}$ in the whole milk (15\%), which is most likely due to the small amount of both elements in the samples. Mn was not quantified in the certified reference material using the IR-MW method and for this reason was not validated in this work, although the results of the determinations of this element in the samples are presented. 
No large differences are observed in the concentrations of the elements in the samples; however, some elements, such as $\mathrm{Ca}, \mathrm{Mg}, \mathrm{Fe}$, and $\mathrm{P}$ are found in slightly lower concentrations in whole milk than in non-fat milk. Usually, non-fat and semi non-fat milk contains lower levels of $\mathrm{Fe}$ compared to whole milk. Consequently, it is very common to add Fe to non-fat and semi non-fat milk powder. Moreover, $\mathrm{Zn}$ and $\mathrm{Ca}$ may also be added, and this kind of milk is named "fortified milk".

Casein is a milk protein that accounts for $80 \%$ of the total protein content of cow's milk, and $66 \%$ of the $\mathrm{Ca}$ in bovine milk is associated with $i^{13}{ }^{13}$. The literature also reports that most of the $\mathrm{Mn}$ in milk samples is associated with the same protein ${ }^{14}$. This suggests that the higher concentrations of these elements in non-fat and semi-non-fat milk are due to preconcentration of the elements contained in the protein phase when milk is defatted.

\subsection{Application of the IR extraction procedure to milk samples}

The efficiency of the IR procedure was evaluated by quantifying the elements in samples of whole and non-fat cow's milk. The complete digestion of the samples in the IRMW system was used to compare the percentage of recovery with that of the proposed extraction methods.

The use of $\mathrm{V}_{2} \mathrm{O}_{5}$ as the oxidizing agent was also studied in the extraction of trace elements from the samples. The results of the trace element quantifications for the different milk samples are shown in Table 4.

The results obtained in both procedures (IR and $I R+V_{2} \mathrm{O}_{5}$ ) were compared through a paired t-test ( $n=3,95 \%$ confidence) with the IR-MW method. The combined standard deviation values $\left(s p^{2}\right)$ were calculated and the $\mathrm{t}$ calculated $(t o b)$ values are shown in Table 5. The critical t value $(t c r=4.30)$ was obtained in the $t$ distribution table for $n=3$ and $95 \%$ confidence. The observed values $(t o b)$ higher than the critical value (tob $>t c r=$ 4.30) are considered different with $95 \%$ confidence.

Table 5. Comparison of procedures using paired t-test values, $95 \%$ confidence, $n=3, t c r=$ 4.30

\begin{tabular}{ccccc}
\hline Element & \multicolumn{2}{c}{ Whole milk } & \multicolumn{2}{c}{ Non-fat milk } \\
\cline { 2 - 5 } & IR-MW / IR & IR-MW / IR+ $\mathrm{V}_{2} \mathrm{O}_{5}$ & IR-MW / IR & IR-MW / IR+ $\mathrm{V}_{2} \mathrm{O}_{5}$ \\
\hline $\mathrm{Ca}$ & 2.93 & -0.70 & 3.30 & 2.40 \\
$\mathrm{~K}$ & 3.81 & -1.93 & 4.13 & 1.48 \\
$\mathrm{Mg}$ & 3.87 & 0.27 & 3.40 & 1.22 \\
$\mathrm{Na}$ & 1.80 & -3.04 & 3.68 & 1.23 \\
$\mathrm{P}$ & -4.06 & -8.99 & 1.83 & 0.30 \\
$\mathrm{Fe}$ & 86.3 & 85.0 & 3.31 & 1.52 \\
$\mathrm{Cu}$ & 2.81 & 3.09 & -1.38 & -2.00 \\
$\mathrm{Mn}$ & 5.60 & 5.60 & - & - \\
$\mathrm{Zn}$ & 13.7 & 9.09 & 4.16 & -1.82 \\
\hline
\end{tabular}


The limits of quantification (LOQ) of the IR procedures were obtained following IUPAC recommendations (10xSD blank / slope) and considering the dilutions. The LOQ determined for $\mathrm{Ca}, \mathrm{K}, \mathrm{Mg}, \mathrm{Na}, \mathrm{P}, \mathrm{Fe}, \mathrm{Cu}, \mathrm{Mn}$ and $\mathrm{Zn}$ are $0.53,2.3,0.027,2.1,23,0.026$, $0.018,0.021,0.030 \mu \mathrm{g} \mathrm{kg}^{-1}$, respectively.

The concentrations determined for $\mathrm{Ca}, \mathrm{K}$, $\mathrm{Mg}, \mathrm{Na}$ and $\mathrm{Cu}$ in the whole milk in both IR procedures (IR and $I R+V_{2} O_{5}$ ) are statistically equal to those obtained following complete decomposition in the IR-MW method, according to the t-test (Table 5). The IR procedure also presents good recovery for $P$ in the whole milk sample.

The relative standard deviation ( $r s d)$ values observed for most of the elements are lower than $5 \%$ only Cu presents rsd of $10 \%$ in both procedures (IR and $I R+V_{2} O_{5}$ ) in the whole milk sample, and Fe presents $r s d$ of using the $I R+V_{2} O_{5}$ procedure in the whole milk sample. The low concentration of this element in the milk samples is likely the main reason of the observed rsd. The IR-MW method presents $24 \%$ rsd in the $\mathrm{Cu}$ determination using $1 \mathrm{~g}$ of whole milk sample, and $12 \%$ rsd using $1 \mathrm{~g}$ of non-fat milk sample. However, using masses of $2 \mathrm{~g}$ in the IR procedures we observe more precision in the result for this trace element using ICPOES technique. It is important to mention that due to the complexity of the matrix, particularly of whole milk, it is not an easy task to determine elements present in very low concentrations in such samples.

There are also some discrepancies in the values obtained for $\mathrm{Fe}, \mathrm{Mn}$ and $\mathrm{Zn}$ concentrations between the methods. The low blank values and also rsd ( $\mathrm{Zn}$ and $\mathrm{Fe}$ ) indicate that this discrepancy is not due to contaminations. The spectral interference caused by incomplete decomposition of the organic matter ${ }^{15}$ and the low concentrations of these elements in milk samples as well, may be the reasons for the different values observed.

The low cost IR proposed method can be used with accuracy to the determination of the major elements $(\mathrm{Ca}, \mathrm{K}, \mathrm{Mg}, \mathrm{Na}$ and $\mathrm{P})$ in the whole and non-fat milk samples. Regarding to the minor elements, the analysis of $\mathrm{Cu}, \mathrm{Fe}$ and $\mathrm{Zn}$ show accurate results in the non-fat milk samples.

The $I R$ and $I R+V_{2} O_{5}$ procedures present effective solubilization of the non-fat milk sample and allowed the accurate determination of $\mathrm{Ca}, \mathrm{K}, \mathrm{Mg}, \mathrm{Na}, \mathrm{P}, \mathrm{Fe}, \mathrm{Cu}$ and $\mathrm{Zn}$ by ICP-OES. Even using $2 \mathrm{~g}$ of this sample in the procedures (IR and $\left(\mathrm{R}+\mathrm{V}_{2} \mathrm{O}_{5}\right)$ the incomplete decomposition of the organic matter did not show interferences in the analysis of the minor elements ( $\mathrm{Zn}$ and $\mathrm{Fe}$ ) affording the statistically similar values (Table 5). The availability of the minor elements into solution and the accurate determination by ICP-OES was possible also due to the fact of whole milk contains $3.8 \%$ fat while non-fat milk contains less than $0.1 \%$ fat.

The relative standard deviation ( $r s d)$ values observed for the elements are lower than $10 \%$ only Ca presents $r$ sd of $17 \%$ in the $\mathrm{IR}+\mathrm{V}_{2} \mathrm{O}_{5}$ procedure in non-fat milk sample.

These results demonstrate the possibility of using only one IR lamp for pre-digestion of milk and quantification of trace elements, using higher masses of samples than in conventional wet digestion methods.

\section{Conclusion}

The present study describes the use of IR radiation as an alternative in milk sample preparation and trace element analysis.

The IR-MW method was effective for decomposition of high masses of samples with complete digestion and the results are comparable to the certified reference material, which demonstrates the efficiency and viability of the use to increase sample mass in wet decomposition of milk samples. IR radiation extraction proposed procedure is as rapid as wet microwave procedures, however is low cost and may be more easily applied in industries and routine analytical laboratories. Furthermore, the method shows low rsd values and presents the 
possibility to use large sample masses, allowing the trace analysis by inexpensive optical techniques as atomic absorption spectroscopy (FAAS), or multielement techniques as ICP-OES with comparable limits of detection. Further experiments should be performed to study the mechanism of IR radiation that promotes solubilization/decomposition of organic samples and its application to different complex samples.

Experiments are currently being conducted by our group to elucidate the mechanism by which IR radiation promotes the extraction of trace elements from complex organic samples for use in optical analysis methods. However, our preliminary results indicated that the method, which can exploit larger sample masses and is cheaper than conventional wet digestion methods, may be applied to common laboratory trace analyses, and provides the possibility of analyzing elements at very low concentrations using moderate-sensitivity equipment.

\section{Acknowledgment}

The authors W. V. Sousa and F. L. F. Silva are grateful to the CAPES (Coordenação de Aperfeiçoamento de Pessoal de Nível Superior, Brazil) for scholarship.

\section{References}

${ }^{1}$ Silva, F. V. S.; Lopes, G. S.; Nóbrega, J. A.; Souza, G. B.; Nogueira, A. R. A. Study of protein-bound fractions of calcium, iron, magnesium, and zinc in bovine milk. Spectrochimica Acta: Part B 2001, 56, 1909. [CrossRef]

2 Zurera-Cosano, G.; Moreno-Rojas, R.; Amaro-Lopes, M. Effect of processing on contents and relationships of mineral elements on milk. Food Chemistry 1994, 51, 75. [CrossRef]
${ }^{3}$ Aleixo, P. C.; Nóbrega, J. A. Direct determination of iron and selenium in bovine milk by graphite furnace atomic absorption spectrometry. Food Chemistry 2003, 83, 457. [CrossRef]

${ }^{4}$ Luo, Y.; Zhang, B.; Chen, M.; Wang, J.; Zhang, X.; Gao, W. Y.; Huang, J. F.; Fu, W. L. Rapid and simultaneous determination of essential minerals and trace elements in human milk by improved flame atomic absorption spectroscopy (FAAS) with microwave digestion. Journal of Agriculture and Food Chemistry 2010, 58, 9396. [CrossRef]

${ }^{5}$ Bizzi, C. A.; Barin, J. S.; Garcia, E. E.; Nobrega, J. A.; Dressler, V. L.; Flores, E. M. M. Improvement of microwave-assisted digestion of milk powder with diluted nitric acid using oxygen as auxiliary reagent. Spectrochimica Acta: Part B 2011, 66, 394. [CrossRef]

${ }^{6}$ Pereira, J. S. F.; Pereira, L. S. F.; Schmidt, L.; Moreira, C. M.; Barin, J. S.; Flores, E. M. M. Metals determination in milk powder samples for adult and infant nutrition after focused-microwave induced combustion. Microchemical Journal 2013, 109, 29. [CrossRef]

${ }^{7}$ Da Silva, S. V.; Picoloto, R. S.; Flores, E. M. M.; Wagner, R.; Dos Santos Richards, N. S.; Barin, J. S. Evaluation of bromine and iodine content of milk whey proteins combining digestion by microwave-induced combustion and ICP-MS determination. Food Chemistry 2016, 190, 364. [CrossRef]

${ }^{8}$ Howard, A. G.; Statham, P. J. Inorganic trace analysis - Philosophy and practice. John Wiley \& Sons, England, 1993.

${ }^{9}$ Gouveia, S. T.; Fatibelo-Filho, O.; Nóbrega, J. A. Infra-red heating as an alternative technique for fast sample preparation. Journal of the Brazilian Chemical Society 2000, 3, 261. [CrossRef]

${ }^{10}$ Magalhães, C. E. C.; Krug, F. J.; Fostier, A. $H$.; Berndt, $H$. Direct determination of mercury in sediments by atomic absorption spectrometry. Journal of Analytical. Atomic Spectrometry 1997, 12, 1231. [CrossRef] 
${ }^{11}$ Dantas, A. N. S.; Matos, W. O.; Gouveia, S. T.; Lopes, G. S. The combination of infrared and microwave radiation to quantify trace elements in organic samples by ICP OES. Talanta 2013, 107, 292. [CrossRef]

${ }^{12}$ Ruiz-Lopes, M. D. Levels of Se, $\mathrm{Zn}, \mathrm{Mn}$ and $\mathrm{Ca}$ in commercial goat and cow milk fermented products: Relationship with their chemical composition and probiotic starter culture. Food Chemistry 2011, 129, 1126. [CrossRef]

${ }^{13}$ Bobbio, F. O. F.; Bobbio, P. A. Introdução à Química de Alimentos. Livraria Varela, São Paulo, Brazil, 1989.
${ }^{14}$ Fuente, M. A.; Guerrero, G.; Juarez, M. Manganese and Zinc analysis in milk by microwave oven digestion and platform graphite furnace atomic absorption spectrometry. Journal of Agricultural and Food Chemistry 1995, 43, 2406. [CrossRef]

${ }^{15}$ Korn, M. G. A.; Oliveira, E. Determinação de zinco em baixas concentrações por espectrofotometria de emissão atômica com plasma de argônio indutivamente acoplado uma comparação crítica entre diferentes linhas de emissão e possibilidade de uso de meio aquoso-orgânico. Química Nova 1996, 19, 488. [Link] 